\title{
Apartheid lever i Bosnien
}

\section{Tihomir Loza}

\section{Selv om der er love til sikring af ligestilling imel- lem de tre store nationaliteter i Bosnien-Hercego- vina, skal ingen regne med social opstigning, hvis de ikke lever blandt 'deres egne'}

Fahrudin Radoncic, ejeren af det største bosniakiske (muslimske) dagblad, Dnevni Avaz, og af en række andre medier, skabte overskrifter sent i januar med udtalelser om, at en etnisk serbisk journalist, der indtil for nylig var redaktør ved landets største tv-station, aldrig skulle have haft jobbet med den etniske baggrund.

Federal Television (FTV), hvor journalisten Duska Jurisic er et af de kendteste ansigter, er del af landets offentlige radio-tv system. FTV ses især i områder med bosniakisk flertal.

Bortset fra at han er en af Bosniens rigeste mænd, har Radoncic, som bespottes og beundres som 'Bosniens Berlusconi', siden september sidste år været leder af et nyt politisk parti, Unionen for en Bedre Fremtid.

Radoncic fordømte især FTV's dækning af Bosniens Muslimske
Samfund, hvis leder Mustafa Ceric er Radoncics nære allierede. "Vi kan ikke tillade, at Jurisic, som ikke er muslim, redigerer dækningen af vort Islamiske Samfund", sagde Ceric som et ekko af Radoncic. I flere efterfølgende interview gentog Radoncic sine racistiske udtalelser og tilføjede for god ordens skyld en række personlige fornærmelser. Han beskrev Duska Jurisic som en frustreret journalist og 'en ignoramus'. Samtidig kunne en artikel i en af hans publikationer i sidste måned om Jurisic og tre andre kvindelige journalister kun beskrives som en øvelse i kvindefjendsk hadpropaganda.

\section{Anklagere vender ryggen til}

Radoncics udtalelser er i strid med bosnisk lov, som forbyder offentlige ytringer af etniske eller religiøse fordomme, diskrimination af etniske 
eller religiøse grunde, kønsdiskrimination og hadpropaganda. Men da dette er Bosnien, holder anklagere næsten per automatik fingrene væk fra sådanne sager.

Som Ivan Lovrenovic, Bosniens nok mest begavede samfundspolitiske tænker, skrev i en artikel i magasinet Dani, var der kun få reaktioner på Radoncics udtalelser. Men de få, som reagerede, gjorde det i stærke vendinger. Bosniens Journalistforbund beskrev udtalelserne som nationalistiske og racistiske og stemplede dem som 'hadpropaganda'. Journalistforbundet krævede, at anklagemyndigheden rejste sag imod Radoncic, og at valgkommissionen skred ind imod hans parti.

Præsidenten for Bosniens Helsinkikomite for Menneskerettigheder, Srdjan Dizdarevic, sagde, at Radoncic udtalelser "var uacceptable, nynazistiske og ekstremt farlige for et multietnisk samfund, ja for ethvert frit samfund". Enkelte andre offentlige figurer protesterede, men de fleste, inklusive folk, som havde til opgave at overvåge medierne, forblev tavse. Hvorfor mon?

I nogle tilfælde var der indlysende og ret prosaiske grunde. Formanden for Bosniens PEN Center, der nægtede at kommentere Radoncics angreb på Jurisic, skriver en fast klumme for en af Radoncics publikationer, der i 15 år har været blandt regionens mest vulgære ud over at være nationalistisk. Andre viger måske bare tilbage for at lægge sig ud med en mand, der er kendt som hensynsløs og som kontrollerer en stor del af Bosniens offentlige mening. Og han kan meget vel få formel politisk magt ved parlamentsvalget $\mathrm{i}$ oktober.

Nogle uafhængige personligheder kan simpelthen generelt være tilbageholdende med at give sig offentligt til kende, fordi de ser Radoncics seneste nationalistiske udfald som bare endnu en beklagelig, men mindre episode i opvarmningen til en valgkampagne, der ventes at blive mere beskidt end nogen tidligere.

Og vi har i sandhed hørt lignende opfordringer til etnisk og religiøs udskillelse mange gange før i Bosnien. Sidste år, da en imam blev fundet skyldig i seksuelt misbrug af en 10-årig pige, fordømte Mustafa Ceric pigens familie for at have hyret en advokat, der tilfældigvis var serber, til at tale deres sag i retten. Ifølge Ceric var advokaten som ikkemuslim ude af stand til at forstå sagen og bosniske muslimer i det hele taget.

\section{Muslimer kan ikke dømme serbere}

Og det omvendte er også tilfældet. Da den statslige anklagemyndighed i 2008 beordrede en undersøgelse af regeringen under Milorad Dodik, ministerpræsident i Bosniens serbiske enhed, Republika Srpska, kaldte Dodik det 'helt uacceptabelt', at sagen blev behandlet af 'muslimske dommere'. Kun et par stykker i Re- 
publika Srpskas civilsamfund og ingen serbiske politiske partier fordømte Dodiks erklæring. Men det forhold, at vi har været her før, gør ikke sagen mindre vigtig.

Et antal politiske positioner er reserveret til repræsentanter for de tre 'constituent peoples', bosniaker (muslimer), kroater og serbere, som i landets tredelte præsidentskab eller parlamentets overhus. Men ellers skulle folks etniske baggrund eller bopæl ikke være en forhindring for at få en offentlig stilling, ifølge Bosniens forskellige forfatninger. Men i realiteten bestemmes dine muligheder i meget høj grad af dit navn og af, hvor du bor. Du skal ikke stræbe særlig højt, hvis du er bosniak i Republika Srpska eller i den kroatiske del af den BosniakiskKroatiske Føderation. Og du skal heller ikke stile højt, hvis du er etnisk serber eller kroat i dele af Føderationen med bosniakisk flertal.

Det har været en stiltiende accepteret norm siden krigen 1992-1995, der efterlod landet i praksis delt imellem tre stort set monoetniske territorier som hjem for tre helt adskilte samfund. Bosniens hovedstad, Sarajevo, hvor Radoncic søger at styre, har været en af få undtagelser. Før krigen afspejlede Sarajevo i vidt omfang landets etniske diversitet. I dag udgør én etnisk gruppe det store flertal af befolkningen, som i næsten alle bosniske byer. Bosnien har ikke gennemført en folketælling siden 1991, men den almindelige vur- dering, at bosniaker udgør omkring 90 procent af Sarajevos befolkning, står uimodsagt. Og byen føler sig afgjort bosniakisk, som man kan kalde naturligt, da bosniaker altid har været byens største etniske gruppe.

Men selv i dag er det sjældent, at Sarajevo føles som udelukkende bosniakisk. I vidt omfang skyldes det et relativt højt antal ikke-bosniaker, der er aktive i det offentlige liv som journalisten Jurisic. Det er primært folk, som skabte sig eller begyndte at skabe sig et navn før krigen.

Det store antal ikke-bosniaker i det, som nu primært er en bosniakisk offentlig sfære, har meget at gøre med bosniakisk nationalismes karakter. Den er i hvert fald historisk betragtelig mindre ekskluderende og paranoid end bosnisk serbisk eller bosnisk kroatisk nationalisme. (Ikke bosniaker spiller også betydelige roller i Tuzla, endnu en by med stort bosniakisk flertal).

\section{Sarajevos rige er bosniaker}

Selvfølgelig finder man ikke andre end bosniaker blandt de mest magtfulde og rige i dagens Sarajevo. Det skyldes ikke, at offentligheden i byen ikke vil tolerere ikke-bosniaker blandt de mest driftige. Det afspejler snarere, at de største stykker af kagen skæres inden for eller under kontrol af nogle få bosniakiske organisationer, de to største bosniakiske partier og det Islamiske Selskab.

Selv om Radoncic åbenlyst har ta- 
lenter, som kan bruges i postkonfliktens kaos og den postkommunistiske transition, ville han aldrig have drevet det til noget uden støtte fra Ceric og Alija Izetbegovic, den afdøde grundlægger af Demokratisk Aktion, det dominerende bosniakiske parti, og muslimernes leder under krigen. Radoncic ville som bosniak heller ikke have drevet det ret langt i Dodiks Banja Luka, hvor spillets regler i toppen af business og politik udelukkende bestemmes af serbiske partier.

Selv om de sjældent kommer helt til tops, har ikke-bosniaker i Sarajevo alligevel ret synlige positioner i medier, kultur, akademiske institutioner, politik og selv i retssystemet. Deres etnicitet understreger i sig selv deres fremtrædende rolle. De er ofte højt respekterede af flertallet for at afvise af tilslutte sig de nationalistiske tilbøjeligheder blandt deres serbiske eller kroatiske etniske fæller, der er endt med at føre kriminelle kampagner til retfærdiggørelse af folkemord på bosniske muslimer. Som mennesker, der som regel støtter en politisk fortælling, der i vidt omfang overlapper, om end sjældent er helt identisk med den gængse bosniakiske fortolkning af fortiden, er de højt skattede af den mere liberale del af det bosniakiske samfund som levende beviser for, at et civiliseret og multietnisk Bosnien er muligt.

Men er deres relativt stærke position i Sarajevos offentlige liv mere end en fodnote i det, som i sidste instans er en ret håbløs opdeling af landet langs etniske linjer i tre samfund? Det er det af følgende årsag.

\section{Det gamle tigerskind væk}

Førkrigstidens gamle Bosnien, som ifølge fablen var et etnisk mønster kaldet 'tigerskind', vil ikke blive genskabt. De fleste mennesker vil blive, hvor de er nu. I overskuelig fremtid vil Bosnien fortsætte som et enkelt land opdelt i tre samfund. Men hvordan Bosniens tre samfund behandler dem, som i realiteten er minoriteter iblandt dem, vil få inflydelse på omfanget og kvaliteten af samspillet imellem dem. Og det vil igen afgøre, om bosnierne vil fortsætte med at leve i et internationalt sponsoreret limbo eller i et regulært samfund, som de kan dele fuldt ud som deres eget.

Og endnu vigtigere vil minoritetsgruppernes position inden for disse tre samfund bestemme og være den vigtigste måler for niveauet af deres interne demokratisering. Hvis Sarajevo skal blive et virkelig tolerant og mere behageligt sted for alle, må folk som Jurisic bedømmes, uden at deres etnicitet nogensinde spiller med i ligningen. Det burde end ikke diskuteres, at hun som enhver anden journalist skal være i stand til at se på alle de emner af samfundsmæssig relevans, som hun vælger at interessere sig for.

På samme måde kan Dodik kun 
nære håb om at gøre Republika Srpska til et mere anstændigt samfund, hvis han først begynder at afgifte det offentlige liv for etnisk udelukkelse. Herunder at bane vejen for at dommere, der tilfældigvis er muslimer, kan dømme anklagede, der tilfældigvis er serbere.

Et aktivt civilsamfund er afgørende for at fremme ændringer, der angår menneskerettighederne. Men som afspejling af det, som ofte kal- des civil apati i landet, svigter aktørerne i Bosniens civilsamfund ofte opgaven at protestere højt nok, når folk som Radoncic, Dodik og Ceric åbent opfordrer til etnisk diskrimination.

Tihomir Loza er vicedirektør for Transitions Online, hvor denne artikel blev bragt 12. februar.

Oversat fra engelsk af Vibeke Sperling. 